\title{
Karyotypes of Japanese Species of the Genus Trimeresurus
}

\author{
MICHIHISA TORIBA
}

\begin{abstract}
The karyotypes of four species of Japanese Trimeresurus are described. They are similar to each other and the diploid number is $2 \mathrm{n}=56$ with 16 macro- and 20 microchromosomes. In all species, the sex chromosomes of $\mathrm{ZW}$ type are recognized. The three species of them have the second pair similar to that of the new world pitvipers, while remaining $T$. okinavensis has a slightly larger arm ratio which approaches that of Asian Agkistrodon. C-banded karyotypes are described for $T$. flavoviridis and $T$. okinavensis. The latter has a portion heavily stained on the longer arms of 1st and 2nd pairs, which correspond to the secondary constrictions observed in some metaphase plates. These are not observed in the former.
\end{abstract}

Key Words: Crotalinae; Trimeresurus; Karyotype; C-banded pattern; Secondary constriction

There are four species of the genus Trimeresurus in the Ryukyu Archipelago, Japan. Among them, T. flavoviridis and T. okinavensis were reported to have the diploid number $2 \mathrm{n}=36$ by Makino and Momma (1949) using classical techniques. Similar figures were also reported on two species of the genus in Taiwan, namely $T$. stejnegeri and $T$. mucrosquamatus, by Nakamura (1935). The karyotypes of these two species were later examined using modern techniques by $\mathrm{Qu}$ et al. (1981) and the observation by Nakamura was confirmed by them.

In the present study, the karyotypes of all four species of the genus Trimeresurus in Japan are described and compared with those of other crotaline snakes. In $T$. flavoviridis and $T$. okinavensis, C-banded karyotypes were examined in addition to the Giemsa stained karyotypes.

\section{Materials and Methods}

The origins and the number of specimens examined are as follows:

T. flavoviridis, two females and two males from Tokunoshima Is. and a female* from Okinawa Is.

T. tokarensis, two females from Takarajima Is.

T. elegans, three females from Ishigakijima Is.

T. okinavensis, two females* from Okinawa Is.

Among them, C-banded karyotypes were observed in the specimens with the asterisks.

The procedure for observing metaphase chromosomes was the same as that described earlier by me (Yosida and Toriba, 1986a;

Accepted 23, May 1989
Toriba, 1987) and the chromosomes were observed from bone marrow of the ribs. On the Cbanded karyotypes, the BSG method of Sumner (1972) was applied with a slight modification. The preparations were dried without using a gas flame, then treated consecutively with $0.2 \mathrm{~N} \mathrm{HCl}$ for $1 \mathrm{hr} ; 5 \% \mathrm{Ba}(\mathrm{OH})_{2}$ at $50^{\circ} \mathrm{C}$ for 30 to $40 \mathrm{~min}$; $2 \times \mathrm{SSC}$ at $60^{\circ} \mathrm{C}$ for $1 \mathrm{hr}$; and stained with $4 \%$ Giemsa solution in phosphate buffer of $\mathrm{pH} 6.8$. The measurements were made on 10 to 15 wellspread metaphase plates, and nomenclature follows Levan et al. (1964).

\section{ReSUlTS}

Numbers of well-spread metaphase plates were observed for all four species, in which the diploid number was $2 n=36$, with 16 macro- and 20 microchromosomes. The karyotypes are shown in Fig. 1 and the measurements in Table 1. As seen in them, the karyotypes of these species are similar to each other. The fourth largest pair is sex chromosomes and composed of a metacentric $\mathrm{Z}$ and submeta- or subtelocentric W-chromosome. Among autosomes, the first, 3rd, 4th and 6th pairs are metacentric in all the forms.

On the other hand, three other pairs show larger variation. The second pair has larger value of arm ratio than the first pair with that of T. okinavensis largest. The 5th and 7th pairs are submeta- or subtelocentric with the exception of the 7th pair of $T$. elegans which is metacentric. However, the 7 th pair was small and the preparation of the metaphase chromosomes of $T$. elegans was relatively poor among four species. Thus this difference should not be considered seriously. Among ten pairs of microchromosomes the largest one was recognized as metacentric and others seemed to be 
a 888888 88 on an on 89 $\bullet \bullet \bullet \bullet \bullet \bullet \bullet \bullet \bullet \bullet \bullet \bullet \bullet \bullet \bullet \bullet \bullet \bullet$

B 8188 88 $8 x$ an as ax 84

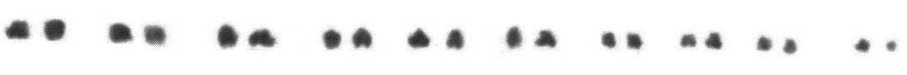

c XK XIX $x \times x \times \times n \times x \times x \times x n$ - $-\infty,-\infty \ldots \ldots \ldots$

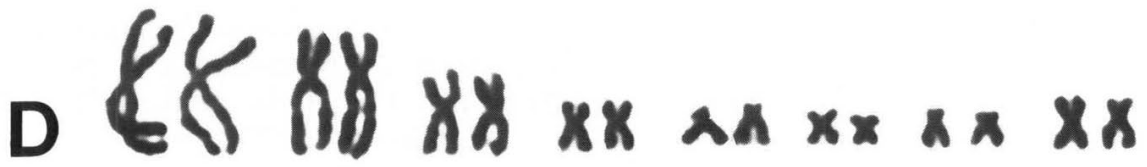
z W

E Z W !

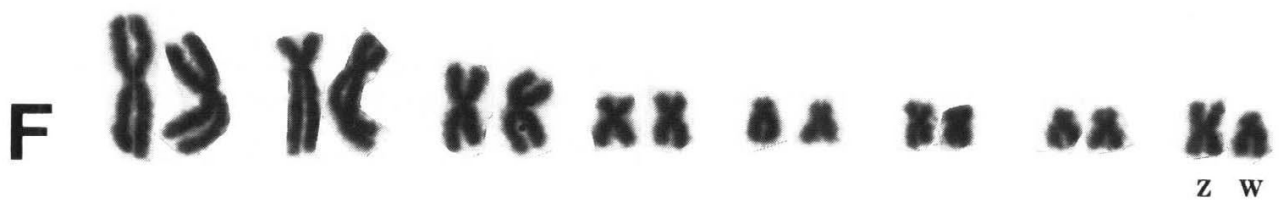
$\bullet+\cdots+\infty+\infty, \ldots+\ldots$ 
TABLE 1. The relative length (RL, \%) and arm ratio (AR) of the macrochromosomes of Japanese species of the genus Trimeresurus and some other crotaline species for the comparison.

\begin{tabular}{|c|c|c|c|c|c|c|c|c|c|c|}
\hline & & \multicolumn{9}{|c|}{ Number } \\
\hline & & 1 & 2 & 3 & 4 & 5 & 6 & 7 & $\mathrm{Z}$ & W \\
\hline T. flavoviridis & $\begin{array}{l}\text { RL } \\
\text { AR }\end{array}$ & $\begin{array}{r}26.0 \\
1.2\end{array}$ & $\begin{array}{r}21.9 \\
1.5\end{array}$ & $\begin{array}{r}15.2 \\
1.2\end{array}$ & $\begin{array}{l}8.9 \\
1.3\end{array}$ & $\begin{array}{l}6.6 \\
3.2\end{array}$ & $\begin{array}{l}6.1 \\
1.6\end{array}$ & $\begin{array}{l}5.5 \\
2.5\end{array}$ & $\begin{array}{r}10.0 \\
1.2\end{array}$ & $\begin{array}{l}7.9 \\
3.7\end{array}$ \\
\hline T. tokarensis & $\begin{array}{l}\text { RL } \\
\text { AR }\end{array}$ & $\begin{array}{r}26.8 \\
1.1\end{array}$ & $\begin{array}{r}20.1 \\
1.7\end{array}$ & $\begin{array}{r}13.9 \\
1.2\end{array}$ & $\begin{array}{l}9.0 \\
1.4\end{array}$ & $\begin{array}{l}7.3 \\
2.6\end{array}$ & $\begin{array}{l}6.8 \\
1.3\end{array}$ & $\begin{array}{l}6.0 \\
2.3\end{array}$ & $\begin{array}{r}10.3 \\
1.2\end{array}$ & $\begin{array}{l}7.8 \\
3.7\end{array}$ \\
\hline T. elegans & $\begin{array}{l}\mathrm{RL} \\
\mathrm{AR}\end{array}$ & $\begin{array}{r}27.2 \\
1.2\end{array}$ & $\begin{array}{r}20.8 \\
1.6\end{array}$ & $\begin{array}{r}14.7 \\
1.2\end{array}$ & $\begin{array}{l}8.9 \\
1.5\end{array}$ & $\begin{array}{l}6.5 \\
2.0\end{array}$ & $\begin{array}{l}6.5 \\
1.2\end{array}$ & $\begin{array}{l}5.5 \\
1.6\end{array}$ & $\begin{array}{r}10.2 \\
1.5\end{array}$ & $\begin{array}{l}7.7 \\
2.3\end{array}$ \\
\hline T. okinavensis & $\begin{array}{l}\text { RL } \\
\text { AR }\end{array}$ & $\begin{array}{r}26.9 \\
1.3\end{array}$ & $\begin{array}{r}22.1 \\
2.2\end{array}$ & $\begin{array}{r}15.2 \\
1.1\end{array}$ & $\begin{array}{l}8.5 \\
1.5\end{array}$ & $\begin{array}{l}6.9 \\
3.2\end{array}$ & $\begin{array}{l}6.3 \\
1.2\end{array}$ & $\begin{array}{l}5.2 \\
3.0\end{array}$ & $\begin{array}{l}9.0 \\
1.5\end{array}$ & $\begin{array}{l}8.1 \\
1.9\end{array}$ \\
\hline B. jararaca $^{1)}$ & $\begin{array}{l}\mathrm{RL} \\
\mathrm{AR}\end{array}$ & $\begin{array}{l}26 \\
1.1\end{array}$ & 21 & $\begin{array}{l}15 \\
1.2\end{array}$ & $\begin{array}{l}8 \\
1.6\end{array}$ & $\begin{array}{l}7 \\
2.7\end{array}$ & $\begin{array}{l}7 \\
1.5\end{array}$ & $\begin{array}{l}6 \\
2.3\end{array}$ & $\begin{array}{l}10 \\
1.1\end{array}$ & $\begin{array}{l}7 \\
3.5\end{array}$ \\
\hline C. durissus ${ }^{1)}$ & $\begin{array}{l}\text { RL } \\
\text { AR }\end{array}$ & $\begin{array}{l}26 \\
1.1\end{array}$ & $\begin{array}{l}21 \\
1.6\end{array}$ & $\begin{array}{l}15 \\
1.0\end{array}$ & $\begin{array}{l}9 \\
1.6\end{array}$ & $\begin{array}{l}7 \\
2.6\end{array}$ & $\begin{array}{l}7 \\
1.5\end{array}$ & $\begin{array}{l}6 \\
2.2\end{array}$ & $\begin{array}{l}10 \\
1.2\end{array}$ & $\begin{array}{l}6 \\
2.2\end{array}$ \\
\hline A. contortrix ${ }^{2}$ & $\begin{array}{l}\text { RL } \\
\text { AR }\end{array}$ & $\begin{array}{r}25.7 \\
1.0\end{array}$ & $\begin{array}{r}20.4 \\
1.5\end{array}$ & $\begin{array}{r}13.6 \\
1.1\end{array}$ & $\begin{array}{l}9.5 \\
1.4\end{array}$ & $\begin{array}{l}7.3 \\
1.2\end{array}$ & $\begin{array}{l}6.6 \\
2.7\end{array}$ & $\begin{array}{l}6.1 \\
1.8\end{array}$ & $\begin{array}{r}10.9 \\
1.2\end{array}$ & \\
\hline A. blomhoffii ${ }^{3}$ & $\begin{array}{l}\text { RL } \\
\text { AR }\end{array}$ & $\begin{array}{r}26.9 \\
1.1\end{array}$ & $\begin{array}{r}21.3 \\
2.5\end{array}$ & $\begin{array}{r}15.0 \\
1.2\end{array}$ & $\begin{array}{l}8.7 \\
1.8\end{array}$ & $\begin{array}{l}6.5 \\
2.9\end{array}$ & $\begin{array}{l}6.2 \\
1.9\end{array}$ & $\begin{array}{l}5.5 \\
2.8\end{array}$ & $\begin{array}{l}9.7 \\
1.1\end{array}$ & $\begin{array}{l}7.5 \\
3.1\end{array}$ \\
\hline$T$. stejnegeri $\left.{ }^{4}\right)$ & $\begin{array}{l}\mathrm{RL} \\
\mathrm{AR}\end{array}$ & $\begin{array}{r}24.1 \\
1.1\end{array}$ & $\begin{array}{r}20.0 \\
2.0\end{array}$ & $\begin{array}{r}15.2 \\
1.5\end{array}$ & $\begin{array}{l}9.0 \\
1.8\end{array}$ & $\begin{array}{l}8.0 \\
6.7\end{array}$ & $\begin{array}{l}7.2 \\
2.1\end{array}$ & $\begin{array}{r}6.1 \\
11.5\end{array}$ & $\begin{array}{r}10.2 \\
1.5\end{array}$ & \\
\hline
\end{tabular}

1) Beçak (1965). ${ }^{2)}$ recalculated from De Smet (1978). ${ }^{3)} A . b$. blomhoffii, present study. ${ }^{4)}$ Qu et al. (1981).

subtelo- or telocentric.

In some of the metaphase plates of $T$. okinavensis, a structure like a secondary constriction was seen in the longer arm of the largest pair (Fig. 2). A similar one was more feebly seen in the second pair. In the C-banded karyotype of this species, the corresponding positions of these secondary constrictions were best stained, although centromeres of each pair and the Wchromosome were only weakly stained (Fig. 2). On the other hand, the C-banded karyotype of T. flavoviridis did not show such a structure, and only centromeres of each pair and Wchromosomes were well stained (Fig. 3). Although a special structure was not recognized in Giemsa stained karyotype, a slightly well stained portion was recognized in the distal end of the longer arm of the second pair.

\section{Discussion}

The present results agree well with those of Makino and Momma (1949). The diploid number of $2 \mathrm{n}=36$ with 16 macro- and 20 microchromosomes are similar to most other crotaline snakes so far examined by previous workers (Beçak, 1965; Baker et al., 1972; Zimmerman and Kilpatrick, 1973; Gutiérrez et al., 1979; Qu et al., 1981). Although De Smet (1978) considered that Bothrops schlegelii has 24 macro- and 12 microchromosomes, observation of his figure and a later study by Gutiérrez et al. (1979) on this species indicate similarity of this species to other species. This pattern is also found in many colubrid and boid snakes.

The submeta- or subtelocentric Wchromosome is also common in crotaline snakes with the exception of a telocentric $\mathrm{W}$ in Agkistrodon contortrix, A. ussuriensis and Sistrurus catenatus (Baker et al., 1972; Yosida and Toriba, 1986b).

Among the slight differences found in the centromeric positions of the pair nos. 2, 5 and 7, I am most interested in the second pair, because most other species of new world Crotalinae have

Fig. 1. The female karyotypes of four species of the genus Trimeresurus with those of the genus Agkistrodon for comparison. (A) T. flavoviridis from Tokunoshima Is. (B) $T$. tokarensis from Takarajima Is. (C) $T$. elegans from Ishigaki-jima Is. (D) T. okinavensis from Okinawa Is. (E) Agkistrodon blomhoffii blomhoffii from Gifu, Japan. (F) A. halys caraganus from USSR. Sex chromosomes are denoted by Z and W. 


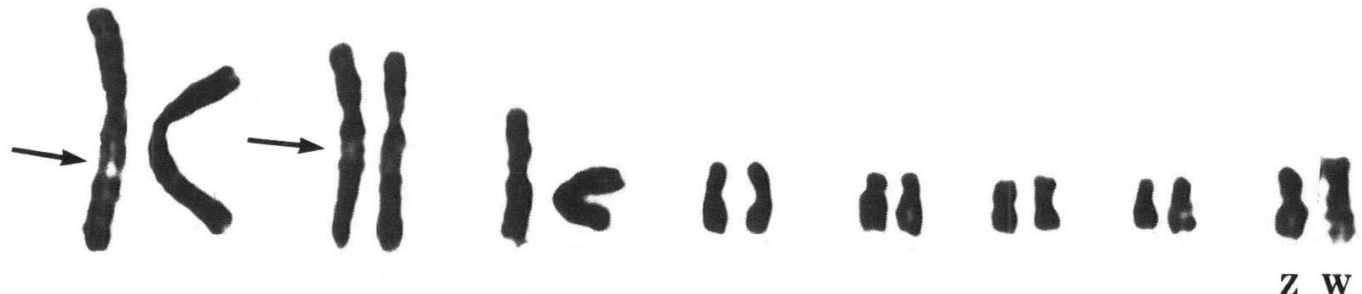

$\mathbf{Z} \mathbf{W}$
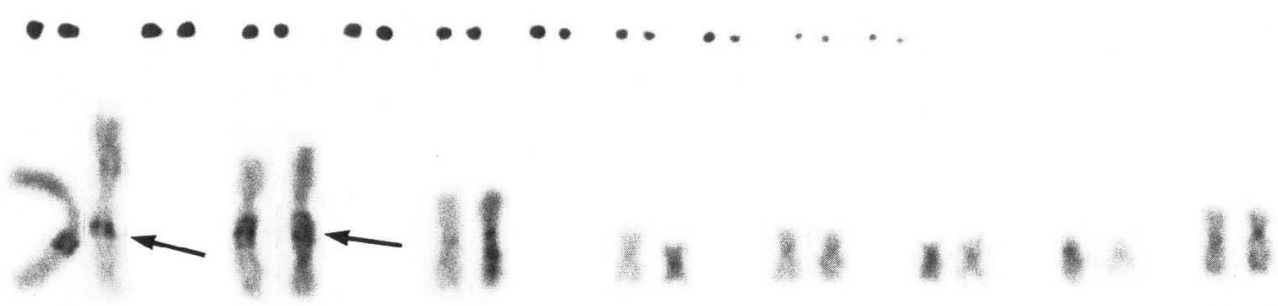

Z W

Fig. 2. Giemsa stained (upper) and C-banded (lower) karyotypes of female Trimeresurus okinavensis. Arrows indicate secondary constrictions and $\mathrm{Z}$ and $\mathrm{W}$ show sex chromosomes.

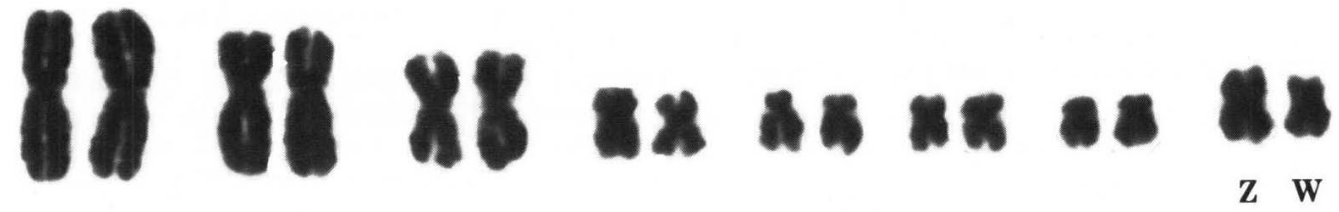

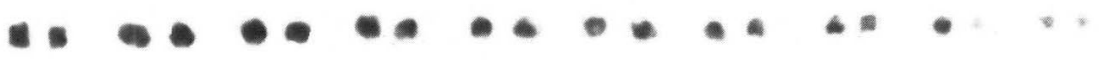
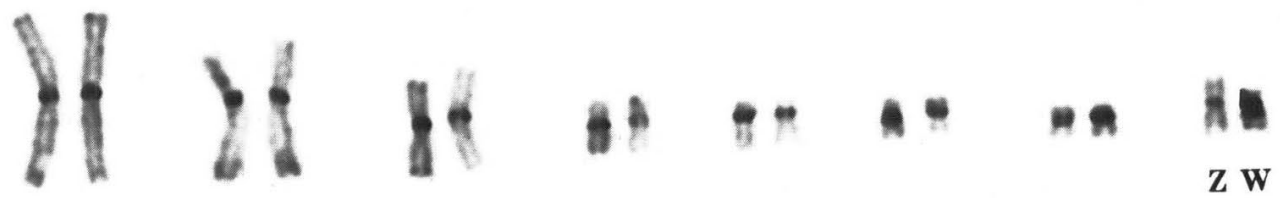

Z W

Fig. 3. Giema stained (upper) and C-banded (lower) karyotypes of female Trimeresurus flavoviridis from Okinawa Is. $\mathrm{Z}$ and $\mathrm{W}$ show sex chromosomes. 
a 1.2-1.7 arm ratio, according to Beçak (1965) and De Smet (1975) and similar value in my calculation from the figures by other workers mentioned above (see also Table 1). On the other hand, Asian Agkistrodon have a far larger value as seen in Fig. $1(\mathrm{E}, \mathrm{F})$ and Table 1. Among the four species of the genus Trimeresurus examined in the present study, three species have a value similar to the new world crotaline snakes, and $T$. okinavensis has a slightly larger value which approaches Asian Agkistrodon. According to Qu et al. (1981), however, T. mucrosquamatus and T. stejnegeri have an intermediate value between them (Table 1). Therefore future study is needed to clarify the problem, though this pair seem to have had some role in the evolution of crotaline snakes.

The difference in the C-banded karyotypes of $T$. flavoviridis and T. okinavensis suggests their remote relationship as claimed by Burger (1971) and Hoge and Romano-Hoge (1981). However, there is no other species whose C-banded karyotype has been examined. The study on the C-banded karyotypes of other species of crotaline snakes will be interesting.

Acknowledgments. - I am indebted to Yoshiharu Kawamura and Yoshio Sawai in obtaining the snakes examined. My colleagues in the institute have helped in many ways. I am grateful to all of them. This work was partially supported by a Grant-in-Aid from the Ministry of Education, Science and Culture, Japan.

\section{Literature Cited}

Baker, R. J., G. A. Mengden and J. J. Bull. 1972. Karyotypic study of thirty-eight species of North American snakes. Copeia 1972: 257-265.

BEçAK, W. 1965. Constituçâo cromossomica e mecanismo de determinaçâo do sexo em ofídios sulamericanos. I. Aspectos cariotípicos. Mem. Inst. Butantan 32: 37-78.

BURGER, W. L. 1971. Genera of pitvipers (Serpentes: Crotalidae). Ph. D. Dissertation, Univ. of Kansas. $186 \mathrm{p}$.

DE Smet, W. H.O. 1978. The chromosomes of 23 species of snakes. Acta. Zool. Pathol. Antverp.
70: 85-118.

Gutiérrez, J. M., R. T. TAylor and R. Bolaños. 1979. Cariotipos de diez especies de serpientes costarricenses de la familia Viperidae. Rev. Biol. Trop. 27(2): 309-319.

Hoge, A. R. ANd S. A. R. W. L. Romano-Hoge. 1981. Poisonous snakes of the world. Part 1. Check list of the pit vipers, Viperoidea, Viperidae, Crotalinae. Mem. Inst. Butantan 42/43: 179-310.

Levan, A., K. Fredga ANd A. A. Sandberg. 1964. Nomenclature for centromeric position on chromosomes. Hereditas 52: 201-220.

Makino, S. And E. Momma. 1949. An idiogram study of the chromosomes in some species of reptiles. Cytologia 15: 96-108.

NaKamura, K. 1935. Studies on reptilian chromosomes. VI. Chromosomes of some snakes. Mem. Coll. Sci. Kyoto Imp. Univ. B10: 361-402.

Qu, Y., X. Xie, Y. Yang, F. Dong and M. Huang. 1981. Chromosomal studies on six species of venomous snakes in Zhejiang. Acta Zool. Sinica 27: 218-227. (in Chinese with English résumé)

SumNer, A. T. 1972. A simple technique for demonstrating centromeric heterochromatin. Exp. Cell Res. 75: 304-306.

Toriba, M. 1987. Karyotypes of some species of the genus Bungarus. Chinese Herpetol. Res. 1987: 1721, pls. 3-5.

Yosida, T. H. ANd M. Toriba. 1986a. Chromosome evolution and speciation of reptiles. I. Karyotype of the Japanese mamushi, Agkistrodon blomhoffii blomhoffii (Viperidae, Crotalinae) with special regard to the sex chromosomes. Proc. Jpn Acad. 62B: $13-16$.

Yosida, T. H. AND M. Toriba. 1986b. Chromosome evolution and speciation of reptiles. II. A comparative study of karyotypes of the Chinese mamushi, (Agkistrodon blomhoffii brevicaudus) and the Ussuri mamushi, (A. ussuriensis) (Viperidae, Crotalinae). Proc. Jpn Acad. 62B: 1720.

Zimmerman, E. G. AND C. W. Kilpatrick. 1973. Karyology of North American crotaline snakes (Family Viperidae) of the genera Agkistrodon, Sistrurus, and Crotalus. Can. J. Genet. Cytol. 15: 389-395.

Japan Snake Institute, Yabuzuka-honmachi, Nitta-gun, Gunma 379-23 JAPAN

\section{要旨 日本産ハブ属の核型}

\footnotetext{
鳥羽 通久

日本産ハブ属 4 種の核型を記述した。すべて $2 n=36$ (大染色体 18 ，小染色体20）でよく似た 核型を持つ。しかし第 2 染色体の腕比がヒ入八 ブで他のものより大きかった。また C一バンド
}

染色をすると，ハブとヒメハブで違いがみられ た。

\section{（379-23 群馬県新田郡薮塚本町 日本蛇族学} 術研究所) 